\title{
Pengaruh Sertifikasi Terhadap Keterampilan Guru dalam Pembuatan Rencana Pelaksanaan Pembelajaran
}

\author{
Aulia Akbar \\ STKIP Sebelas April Sumedang \\ akbaraulia224@gmail.com
}

Article History

accepted 24/09/2019

published 01/12/2019

\begin{abstract}
Effective learning activities require careful planning. When planning the learning activities to be carried out must consider a variety of variables, ranging from the determination of models, methods, tools, evaluation instruments and others in part. This is not easy, it requires extensive and in-depth knowledge in making a learning plan. However, Learning Implementation Plans (RPP) skill making is a skill that must be possessed by every teacher, especially teachers who are already certified. Certified teachers should already have four expected competencies, including: pedagogical, personal, social and professional. So that learning activities in class can run in accordance with what is desired. The purpose of this study is to obtain a picture of whether certification has an effect on teacher skills in making learning implementation plans. Adapu $n$ method used is a survey method using a random sample of eight teachers. The instrument in this study uses scoring / points on the nine principles contained in the 2013 curriculum preparation principles. The results obtained are based on the results of the study being in the very high category. Even though the principles in formulating lesson plans are not yet fully understood. Both certified and non-certified teachers were on average 8.75 or 97.22\%.
\end{abstract}

Keywords: Certification, Teacher, Learning Implementation Plan

\begin{abstract}
Abstrak
Kegiatan pembelajaran yang efektif membutuhkan perencanaan yang matang. Ketika akan merancanakan kegiatan pembelajaran yang akan dilaksanakan harus mempertimbangkan berbagai macam variabel, mulai dari penentuan model, metode, alat, instrumen evaluasi dan lain sebagiannya. Hal ini tentunya tidaklah mudah, dibutuhkan pengetahuan yang luas dan mendalam dalam mambuat sebuah perencanaan pembelajaran. Namun demikian, keterampilan dalam membuat Rencana Pelaksanaan Pembelajaran (RPP) merupakan keterampian yang harus dimiliki oleh setiap guru, terlebih lagi guru yang sudah tersertifikasi. Guru yang telah tersertifikasi seharusnya telah memiliki empat kompetensi yang diharapkan, di antaranya: pedagogik, keperibadian, sosial dan profesional. Sehingga kegiatan pembelajaran di kelas dapat berjalan sesuai dengan apa yang diinginkan. Tujuan penelitian ini yaitu memperoleh gambaran apakah sertifikasi berpegaruh pada keterampilan guru dalam membuat rencana pelaksanaan pembelajaran. Adapun metode yang digunakan adalah metode survei menggunakan sample acak dengan delapan guru. Instrumen pada penelitian ini menggunakan penyekoran/point pada sembilan prinsip yang terdapat pada prinsip penyusunan kurikulum 2013. Hasil yang diperoleh berdasarkan hasil penelitian dengan berada dalam kategori sangat tinggi. Walaupun belum sepenuhnya prinsip-prinsip dalam merumuskan RPP dapat dipenuhu. Baik pada guru yang tersertifikasi maupun yang belum tersertifikasi yang berada pada rata-rata 8,75 atau $97,22 \%$.
\end{abstract}

Kata kunci: Sertifikasi, Guru, Rencana Pelaksanaan Pembelajaran

Social, Humanities, and Education Studies (SHEs): Conference Series https://jurnal.uns.ac.id/shes

p-ISSN 2620-9284 e-ISSN 2620-9292 


\section{PENDAHULUAN}

Mendapatkan pendidikan yang bermutu merupakan hak setiap warga negara. Kewajiban guru adalah memfalisitasi siswa dengan berbagai macam pengetahuan dengan metode efektif, bervariatif, dan efisien sesuai kompetensi yang terdapat dalam kurikulum. Sebagai salah satu pekerjaan yang membutuhkan banyak perhatian dan pengetahuan sudah seyogyanya guru haruslah mempunyai kompetensi yang diharapkan. Berdasarkan Undang-Undang Nomor 14 Tahun 2005 tentang Guru dan Dosen, pada pasal 10 ayat (1) menyatakan bahwa "Kompetensi guru sebagaimana dimaksud dalam Pasal 8 meliputi kompetensi pedagogik, kompetensi kepribadian, kompetensi sosial, dan kompetensi profesional yang diperoleh melalui pendidikan profesi". Salah satu kompetensi yang diharapkan untuk menjadi seorang guru yang berkualitas ketika akan mengajar adalah kompetensi pedagogik dan profesional. Keberhasilan pelaksanaan kegiatan pembelajaran di lingkungan pendidikan formal dan nonformal akan sangat ditentukan oleh kompetensi guru (Siswantari, 2011).

Sorang guru yang memiliki kompetensi akan sangat berpengaruh pada setiap tingkah lakunya, hal ini akan memberikan efek yang sangat positif bagi kegiatan sebelum atau sesudah pembelajaran di kelas, sehingga akan berdampak pada meningkatnya prestasi akademis dan non akademik siswa. Kompetensi guru dalam proses pembelajaran sangat menentukan kemajuan akademik dan nonakademik siswa karena kemampuan guru dalam proses pembelajaran merupakan salah satu pilar utama peningkatan mutu pendidikan (Fransisca \& Ajisuksmo, 2015).

Memiliki ke empat kompetensi akan membuat kualitas seorang guru meningkat. Beberapa penelitian juga menunjukkan bahwa kekuatan suatu bangsa tergantung pada sistem pendidikannya, di mana efektivitas dalam sistem pendidikan tergantung pada kualitas guru (Achwarin, 2009). Bila seorang guru dapat memberikan hal-hal baik pada siswa hal ini akan menimbulkan dampak yang sangat baik bagi perkembangan siswa. Guru-guru yang berkualitas ini akan memberi pengaruh yang sangat positif bagi program pembelajaran (Susanti, 2014). Pada membelajaran di sekolah dasar yang membutuhkan bimbingan lebih, seorang guru haruslah mempunyai pengetahuan dalam memilah dan memilih metode pembelajaran yang cocok pada tingkat perkembangannya sehingga dapat meingkatkan minat siswa terhadap mata pelajaran. McGriff dalam Isman (2011) menyatakan bahwa proses pembelajaran harus fokus pada konteks dan pengalaman yang dapat membuat siswa memiliki minat dan dapat melakukan aktivitas belajar.

Guru yang baik adalah guru yang dapat memfasilitasi kebutuhan siswa serta mensinkronkan tuntutan kurikulum. Mempersiapkan pembelajaran di dalam kelas dengan membuat RPP merupakan salah satu yang dapat dilakukan guru agar pembelajaran dapat berjalan dengan efektif dan efisien. Guru sebagai perancang pembelajaran bertugas membuat rancangan program pembelajaran yang menjadi tanggung jawabnya sesuai dengan kompetensi yang telah ditetapkan (Wahyuni dan Ibrahim, 2012). Rancangan tersebut haruslah sesuai dengan tujuan pendidikan dan kurikulum yang berlaku. Di dalam merumuskan RPP ada beberapa prinsip-prinsip yang dapat dijadikan sebagai acuan dalam pembuatan RPP. Berikut ini merupakan prinsipprinsip dalam penyusunan kurikulum 2013 berdasarkan permendikbud no. 22 tahun 2016.

Indikator Prinsip Penyusunan

Rencana Pelaksanaan Pembelajaran (RPP)

1. Rumusan RPP berdasarkan silabus kurikulum yang berlaku; kurikulum yang diberlakukan harus sesuai dengan apa yang ditetapkan oleh pemerintah, hal ini dilakukan agar adanya keseragaman kurikulum yang diajarkan baik di sekolahsekolah yang berada di daerah perkotaan maupun sekolah yang berada di pedesaan. pemerintah dalam hal ini telah memberlakukan kurikulum 2013 yang 


\begin{tabular}{|c|c|}
\hline & $\begin{array}{l}\text { literapkan di sekolah-sekolah. Pemberlakuan kurikulum } 2013 \text { oleh } \\
\text { tah telah melewati beberapa tahap dari mulai sosialisasi, desiminasi, } \\
\text { dan pelengkapan kebutuhan yang dibutuhkan sekolah seperti pemberian }\end{array}$ \\
\hline 2. & $\begin{array}{l}\text { umusan RPP seusai dengan kondisi di satuan pendidikan (kemampuan awal } \\
\text { serta didik, minat, motivasi belajar, bakat, potensi, kemampuan sosial, emosi, } \\
\text { aya belajar, kebutuhan khusus, kecepatan belajar, latar belakang budaya, } \\
\text { rma, nilai, dan/atau lingkungan peserta didik); perumusan RPP yang } \\
\text { erapkan harus memperhatikan beberapa aspek peserta didik, dimana pada diri } \\
\text { serta didik terdapat potensi yang berbeda dalam menyerap materi yang } \\
\text { perikan guru, perumusan RPP dengan memperhatikan potensi tersebut } \\
\text { enjadikan pelaksanaan pembelajaran labih dapat diminati dan disenangi oleh } \\
\text { swa. selain itu, peumusan RPP dengan memperhatikan latar belakang budaya } \\
\text { an lingkungan serta norma yang berlaku juga akan memudahkan peserta didik } \\
\text { lam mencerna materi karena sesuai dengan aktivitas kehidupan sehari-hari. }\end{array}$ \\
\hline 3. & $\begin{array}{l}\text { umusan RPP mendorong partisipasi aktif peserta didik; pendidikan hari ini telah } \\
\text { engadopsi sebuah pemikiran bahwa dalam pembelajaran di kelas bukan guru } \\
\text { ng banyak beraktivitas namun siswa (student center). Seluruh aktivitas } \\
\text { embelajaran harus berpusat pada siswa karena siswa lah yang belajar. } \\
\text { egiatan- kegiatan dalam pembelajaran juga harus diperhatikan sehingga dapat } \\
\text { elatih seluruh aspek baik aspek, baik aspek kognitif, afektif maupun } \\
\text { ikomotorik. }\end{array}$ \\
\hline 4. & $\begin{array}{l}\text { Imusan proses pembelajaran dalam RPP dirancang dengan berpusat pada } \\
\text { serta didik (mengembangkan motivasi, minat, rasa ingin tahu, kreativitas, } \\
\text { siatif, inspirasi, kemandirian, semangat belajar, keterampilan belajar dan } \\
\text { biasaan belajar); student center dalam pengembangan potensi siswa sangat } \\
\text { orioritaskan diharapkan ketika siswa belajar dengan mengaktifkan segala } \\
\text { tensi yang dimilikinya maka pembelajaran akan manjadi lebih meningkatkan } \\
\text { otivasi, minat rasa ingin tahu dll. yang ada pada siswa. Sehingga kelas akan } \\
\text { oih aktif dan menyenangkan. }\end{array}$ \\
\hline 5. & $\begin{array}{l}\text { musan RPP mengembangkan budaya membaca, menulis dan berhitung; } \\
\text { רgembangan RPP memperhatikan aspek yang paling pondasi dari } \\
\text { ngembangan hidup manusia di antaranya: menulis, membaca dan berhitung. } \\
\text { ggembangan tersebut diharapkan dapat menjadikan siswa menjadi pribadi } \\
\text { g logis, kaya pengalaman dan literasi sehingga dapat bersaing dalam era } \\
\text { g semakin moderen seperti sekarang. Kemempuan literasi yang tinggi kan } \\
\text { pat membawa bangsa Indonesia melek terhadap kemajuan yang terjadi di } \\
\text { uruh penjuru dunia. }\end{array}$ \\
\hline 6 & umusan proses pembelajaran dalam RPP dirar \\
\hline 7. & $\begin{array}{l}\text { musan RPP memuat rancangan program pemb } \\
\text { nguatan, pengayaan, dan remedy (tindak lar }\end{array}$ \\
\hline
\end{tabular}




\begin{tabular}{|l|l|}
\hline 8. & $\begin{array}{l}\text { Rumusan RPP memperhatikan keterkaitan dan keterpaduan antara KI dan KD, } \\
\text { materi pembelajaran, kegiatan pembelajaran, penilaian, dan sumber belajar } \\
\text { dalam satu keutuhan pengalaman belajar; pengembangan harus saling } \\
\text { keterkaitan antara kurikulum yang diberlakukan oleh pemerintah dan keadaan } \\
\text { siswa, oleh karena itu guru haruslah menyesuaikan kegiatan pembelajaran } \\
\text { dengan apa yang telah tertera di silabus, sehingga kompetensi yang dicapai } \\
\text { sekolah (siswa) sejalan dengan apa yang diharapkan pemerintah. Selain itu, } \\
\text { adanya keseuaian dalam penyususnan kurikulum juga dapat menjadi tolak ukur } \\
\text { guru dalam mengevaluasi sejauh mana efektifitas kegiatan pembelajaran di kelas } \\
\text { melalui kegiatan penilaian. }\end{array}$ \\
\hline 9. & $\begin{array}{l}\text { Rumusan RPP disusun dengan mempertimbangkan penerapan teknologi } \\
\text { informasi dan komunikasi secara terintegrasi, sistematis, dan efektif sesuai } \\
\text { dengan situasi dan kondisi; pembelajaran di kelas harus disesuaikan dengan } \\
\text { perkembangan jaman dan disesuaikan dengan situasi kondisi, guru harus } \\
\text { menggunakan teknologi yang kekinian dalam kegiatan pembelajaran sehingga } \\
\text { menjadi relefan dan efektif. }\end{array}$ \\
\hline
\end{tabular}

(Kemendikbud, 2016).

\section{METODE}

Metode yang digunakan dalam penelitian ini adalah menggunakan penelitian survey. Melalui metode survey ini akan didapatkan data asli mengenai hubungan antara sertifikasi guru dengan keterampilan guru dalam pembuatan Rencana Pelaksanaan Pembelajaran.

Lokasi penelitian ini dilakukan di Sekolah Dasar di Kota Sumedang yang terdiri dari delapan Sekolah. Pada penelitian ini dilakukan pemilihan sampel dari populasi tersebut dengan menggunakan teknik random sampling, yaitu dengan memilih secara acak sampel, sehingga diperoleh delapan orang guru yang akan dijadikan bahan penelitian. Adapun jumlah delapan sekolah ini memenuhi standar $15-20 \%$ dari jumlah populasi (Ridwan, 2009).

Teknik pengumpulan data merupakan berbagai cara yang digunakan untuk mempeoleh dan mengumpulkan data penelitian. Dalam penelitian ini digunakan teknik observasi. Teknik analisis data yang digunakan adalah pengolahan data dengan teknik statistika sederhana.

Adapun rumus umum yang digunakan untuk analisis kesesuaian RPP dengan prinsip penyusunan RPP adalah :

$$
\text { F kum }(\%)=\frac{f}{n} x 100 \%
$$

Keterangan :

F kum (\%) : Kesesuaian RPP dengan prinsip penyusunan RPP

$f \quad$ : Jumlah indikator yang muncul

$n \quad:$ Jumlah total indikator

Sebagai standar pengelompokan hasil analisis kesesuaian RPP dengan prinsip penyusunan RPP yang diteliti, maka digunakan kriteria sebagai berikut:

Tabel 1. Kriteria Kesesuaian RPP dengan Prinsip Penyusunan RPP

\begin{tabular}{|c|c|}
\hline Persentase (\%) & Kriteria \\
\hline $81-100$ & Sangat Tinggi \\
\hline $61-80$ & Tinggi \\
\hline
\end{tabular}




\begin{tabular}{|c|c|}
\hline $41-60$ & Cukup \\
\hline $21-40$ & Rendah \\
\hline $0-20$ & Sangat Rendah \\
\hline
\end{tabular}

(Akdon, 2008).

HASIL DAN PEMBAHASAN

Berdasarkan hasil yang diperoleh dari pengumpulan dokumen Rencana Pelaksanaan Pembelajaran (RPP) yang telah dibuat oleh guru yang telah tersertifikasi dan yang belum tersertifikasi yang berorientasi pada prinsip-prinsip pembuatan RPP yang benar adalah sebagai berikut:

Tabel 2. Kesesuaian RPP dengan prinsif Pembuatan RPP

\begin{tabular}{|c|c|c|c|c|}
\hline Sample & $\begin{array}{l}\text { Jumlah } \\
\text { Indikator }\end{array}$ & Persentase & Kategori & Keterangan \\
\hline \multicolumn{5}{|c|}{ Telah Tersertifikasi } \\
\hline S001 & 9 & 100 & Sangat Tinggi & \multirow{4}{*}{$100 \%$ Sangat Tinggi } \\
\hline S002 & 8 & 88,9 & Sangat Tinggi & \\
\hline S003 & 9 & 100 & Sangat Tinggi & \\
\hline S004 & 9 & 100 & Sangat Tinggi & \\
\hline \multicolumn{5}{|c|}{ Belum Tersertifkasi } \\
\hline S005 & 8 & 88,9 & Sangat Tinggi & \multirow{4}{*}{$100 \%$ Sangat Tinggi } \\
\hline S006 & 9 & 100 & Sangat Tinggi & \\
\hline S007 & 9 & 100 & Sangat Tinggi & \\
\hline S008 & 9 & 100 & Sangat Tinggi & \\
\hline Rata2 & 8.75 & 97.22 & $\mathrm{Sa}$ & at Tinggi \\
\hline
\end{tabular}

Bila dilihat dari tabel di atas keterampilan guru dalam melakukan rencana pelaksanaan pembelajaran rata-rata dalam kategori sama (sangat tinggi). Walaupun pada kenyataannnya ada satu guru yang bersertifikasi belum memenuhi $100 \%$ indikator yang ada. Hal tersebut juga terjadi pada guru yang belum tersertifikasi, ada satu guru yang tidak memenuhi satu indikator dalam penyusunan RPP yang benar. Untuk lebih jelasnya penyebaran indikator dalam penyusunan RPP dapat dilihat pada gambar 2 dan 3 berikut ini.

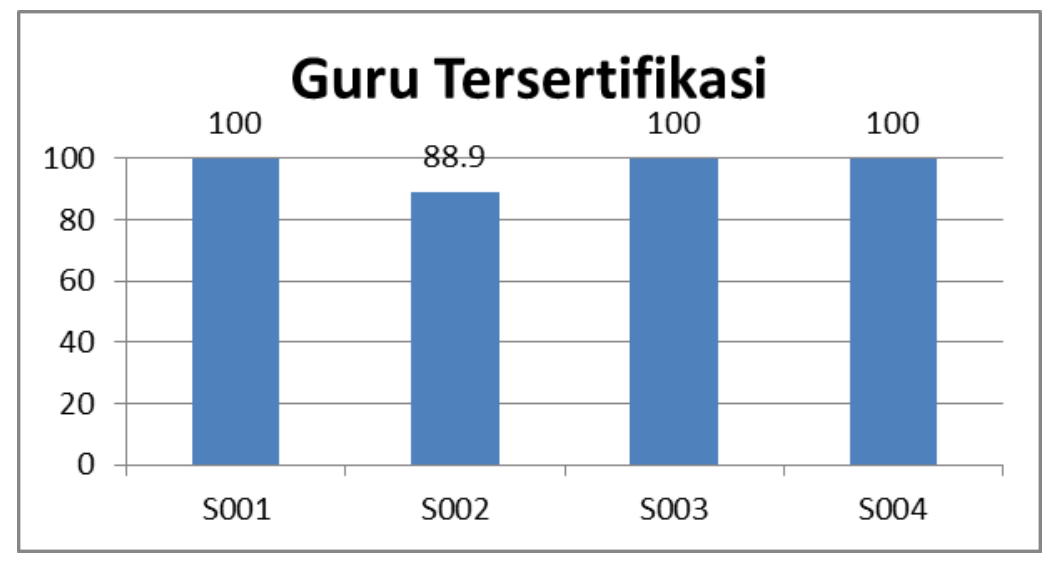

Gambar 1. Grafik Presentase Kesesuaian RPP dengan Prinsip Penyusunan RPP Guru yang Tersertifikasi 
Berdasarkan gambar 1. Mengenai kesesuaian guru dalam dalam membuat RPP dengan prinsip yang ada termasuk dalam kategori sangat tinggi. Pada poin 1 (rumusan RPP berdasarkan silabus kurikulum yang berlaku) subjek S001, S002, S003 dan S004 merumuskan RPP sudah sesuai dengan kurikulum 2013. Sedangkan pada poin 2 (rumusan RPP seusai dengan kondisi di satuan pendidikan; kemampuan awal peserta didik, minat, motivasi belajar, bakat, potensi, kemampuan sosial, emosi, gaya belajar, kebutuhan khusus, kecepatan belajar, latar belakang budaya, norma, nilai, dan/atau lingkungan peserta didik) subjek S002 belum memenuhi kriteria tersebut dikarenakan belum memfasilitasi minat, potensi, emosi, gaya belajar, kecetapan belajar siswa, rencana pelaksanaan dibuat sangat formal tanpa adanya penyesuaian hal-hal tersebut di atas. Sedangkan pada subjek S001, S003, dan S004 dalam RPP terdapat langkah pembelajaran yang lebih spesifik yang memanfaatkan seluruh potensi yang ada pada siswa dalam memenuhi tujuan pembalajaran. Pada point 3 (rumusan RPP mendorong partisipasi aktif peserta didik), dimana subjek S001, S002, S003 dan S004 dalam merumuskan RPP mengacuh pada prinsip student center, dimana dalam pemilihan metode menggunakan metode yang melibatkan siswa aktif dalam pembelajaran. Hal ini juga terlihat pada poin 4 (rumusan proses pembelajaran dalam RPP dirancang dengan berpusat pada peserta didik (mengembangkan motivasi, minat, rasa ingin tahu, kreativitas, inisiatif, inspirasi, kemandirian, semangat belajar, keterampilan belajar dan kebiasaan belajar) dimana terlihat dalam penyusunan rencana pelaksanaan pembelajaran subjek S001, S002, S003 dan S004 sudah memahami serta mempertimbangkan kemampuan peserta didik, sehingga RPP yang dibuat sesuai dengan prinsip tersebut.

Hasil yang diperoleh dari dokumen rencana pelaksanaan yang dibuat oleh subjek S001, S002, S003 dan S004 pada poin 5 (rumusan RPP mengembangkan budaya membaca, menulis dan berhitung) sudah sesuai. Guru menerapkan dan membudayakan literasi pada setiap aktivitas pembelajaran. Poin 6 (rumusan proses pembelajaran dalam RPP dirancang untuk mengembangkan kegemaran membaca, pemahaman beragam bacaan, dan berekspresi dalam berbagai bentuk tulisan) subjek S001, S002, S003 dan S004 juga sudah membuat rumusan RPP agar siswa aktif berekspresi, menanyakan pada guru sesuatu yang belum jelas serta berdiskusi dengan siswa lain. Pada point 7 mengenai (rumusan RPP memuat rancangan program pemberian umpan balik positif, penguatan, pengayaan, dan remedy (tindak lanjut)) subjek S001, S002, S003 dan S004 merumuskan dengan sangat baik, dimana awal, tengah dan akhir terdapat program evaluasi yang dilakukan. Pada poin 8 (Rumusan RPP memperhatikan keterkaitan dan keterpaduan antara $\mathrm{KI}$ dan $\mathrm{KD}$, materi pembelajaran, kegiatan pembelajaran, penilaian, dan sumber belajar dalam satu keutuhan pengalaman belajar) terlihat subjek S001, S002, S003 dan S004 sudah paham bagaimana merumuskan turunan kurikulum 2013 dengan baik sehingga RPP yang dibuat sesuai dengan kurikulum 2013 baik secara sistematika, namun juga secara konten. Pada poin terakhir atau poin 9 (rumusan RPP disusun dengan mempertimbangkan penerapan teknologi informasi dan komunikasi secara terintegrasi, sistematis, dan efektif sesuai dengan situasi dan kondisi) terlihat subjek S001, S002, S003 dan S004 sudah menerapkan teknologi seperti: internet, tv, hand phone, proyektor dalam penyusunan RPP.

Hal tersebut tidak jauh berbeda dengan apa yang terjadi pada guru-guru yang belum tersertifikasi. Hanya terdapat satu poin dalam prinsip pembelajaran yang tidak terdapat dalam penyusunan RPP. Selanjutnya presentase Kesesuaian RPP dengan prinsip penyusunan RPP guru yang belum tersertifikasi dapat di lihat dari gambar 2 berikut ini. 


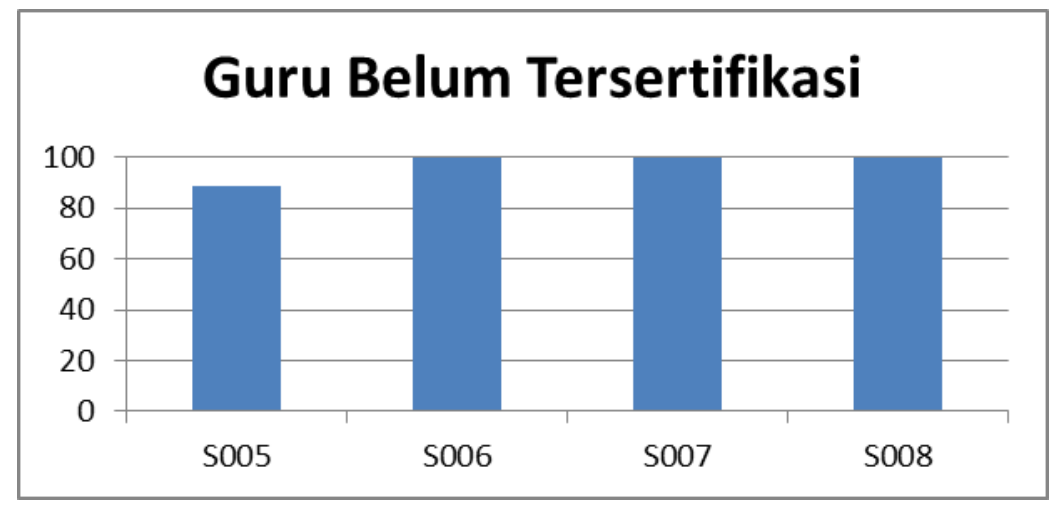

\section{Gambar 2. Grafik Presentase Kesesuaian RPP dengan Prinsip Penyusunan RPP Guru yang Belum Tersertifikasi}

Berdasarkan gambar 2 di atas subjek S005, S006, S007 dan S008 telah dapat menyusun RPP sesuai prinsip-prinsip penyusunan RPP yang terdapat pada permendikbud 2016 yaitu 9 prinsip belum lengkap spenuhnya $(97,22 \%)$. Hal ini dikarenakan pada subjek S005 terdapat satu prinsip yang tidak ada yaitu pada poin 2 (Rumusan RPP seusai dengan kondisi di satuan pendidikan; kemampuan awal peserta didik, minat, motivasi belajar, bakat, potensi, kemampuan sosial, emosi, gaya belajar, kebutuhan khusus, kecepatan belajar, latar belakang budaya, norma, nilai, dan/atau lingkungan peserta didik). Dimana guru belum mempertimbangkan sepenuhnya kemampuan awal peserta didik, minat, motivasi belajar, bakat, potensi, kemampuan sosial, emosi, gaya belajar, kebutuhan khusus, kecepatan belajar, latar belakang budaya, norma, nilai, dan/atau lingkungan siswa dalam perumusan RPP. Guru dalam merumuskan RPP melihat hanya dari gambaran umum siswa tidak spesifik melihat apa yang menjadi kebutuhan siswa.

Dari hasil yang telah diperoleh, keterampilan guru dalam merumuskan RPP belum sepenuhnya lengkap dikarenakan beberapa faktor di antaranya keadaan siswa bervariatif dan pengetahuan guru yang minim terhadap latar belakang siswa. Namun, keterampilan guru dalam merumuskan RPP sudah berada pada kategori sangat tinggi serta mengacuh pada prinsip-prinsip yang berlaku. Rencana Pelaksanaan Pembelajaran (RPP) yang disusun guru harus lebih memperhatikan perkembangan setiap siswa serta menggunakan fasilitas baik sarana dan prasarana yang yang tersedia di sekolah agar pembelajaran lebih efektif dan sesuai dengan perkembangan jaman. (Anggaraeni \& Akbar, 2018).

\section{SIMPULAN}

Pada umumnya keterampilan guru dalam pembuatan Rencana Pelaksanaan Penbelajaran (RPP) berada dalam kategori sangat tinggi atau bisa dikatakan ideal. Namun, pada poin dua (rumusan RPP seusai dengan kondisi di satuan pendidikan (kemampuan awal peserta didik, minat, motivasi belajar, bakat, potensi, kemampuan sosial, emosi, gaya belajar, kebutuhan khusus, kecepatan belajar, latar belakang budaya, norma, nilai, dan/atau lingkungan peserta didik) dimana guru masih belum membuat rencana pelaksanaan pembelajaran yang dapat memfasilitasi minat, motivasi, bakat, potensi, kemampuan, gaya belajar siswa. Pada pembuatan RPP belum sesuai dengan apa yang diharapkan, dalampembuatan RPP guru hanya berpegang pada tujuan pembelajaran atau kompetensi yang harus dimiliki siswa ketika materi telah tersampaikan serta belum menggali berbagai macam latar belakang potensi dan minat siswa. Penggunaan metode, evaluasi yang beragam serta mengenal 
siswa lebih dalam dapat dipertimbangkan guru dalam penyusunan rencana pelaksanaan pembelajaran agar kegiatan pembelajaran dapat berjalan secara aktif, efektif, efisien dan menyenangkan.

\section{DAFTAR PUSTAKA}

Achwarin, N. A. (2009). The study of teacher competence of teachers at schools in the three southern provinces of Thailand. Diunduh dari http://www. journal.au.edu/scholar/2009/word/ nareeAwareAchwarin156.doc

Akdon. (2008). Aplikasi Statistika dan Metode Penelitian untuk Administrasi dan Manajemen. Bandung: Dewa Ruci.

Anggraeni, P. \& Akbar, A. (2018) Analisis Kesesuaian Pencana Pelaksanaan Pembelajaran di Sekolah Dasar Kota Sumedang. Prosiding: Semnas HOTS. STKIP Sebelas April Sumedang.

Francisca, L., \& Ajisuksmo, C. R. P. (2015). Keterkaitan antara moral knowing, moral feeling, dan moral behavior pada empat kompetensi dasar guru. Jurnal Kependidikan, 45(2), 211-221.

Isman, A. (2011). Instructional Design in Education : New Model. The Turkish Online Jurnal of Technology. Vol 10 Issue 1.

Kemendikbud. (2016). Permendikbud No. 22 Tahun 2016 Tentang Standar Proses Pendidikan Dasar dan Menengah. Jakarta: Kemendikbud.

Siswantari. (2011). Kompetensi pendidik dan tenaga kependidikan pada pendidikan nonformal. Jurnal Pendidikan dan Kebudayaan, 17(5).

Susanti, S. (2014). Meningkatkan efektivitas pendidikan nonformal dalam pengembangan kualitas sumber daya manusia. Jurnal Handayani, 1(2)

Wahyuni, S dan Ibrahim, A. S. (2012). Perencanaan Pembelajaran Bahasa Berkarakter. Malang: Refika Aditama 